Журнал «Герспективитаінноваціїнауки»

(Серія «Гедагогіка», Серія «Гиихологія»), Серія«Медицина»

№5(5) 2021

УДК 378

https://doi.org/10.52058/2786-4952 -2021-5(5)-264-275

Дзера Наталія Анатоліївна викладач вищої категорії, старший викладач, викладач хімії та біології, Державний навчальний заклад «Лісоводський професійний аграрний ліцей», вул. Сугерова, 4, с. Лісоводи, 32046, тел.: (097) 897-71-01, e-mail: nataliadzera73@gmail.com

Чубінська Наталія Богданівна доцент кафедри педагогіки та інноваційної освіти Інституту права, психології та інноваційної освіти, Національний університет «Львівська політехніка», вул. Степана Бандери, 14, м. Львів, 79000, тел.: (067) 813-01-58, e-mail: nataliialviv2015@ gmail.com, https://orcid.org/0000-0002-4803-2453

Земляк Наталія Іванівна викладач вищої категорії, викладач-методист, викладач української мови та літератури, Державний навчальний заклад «Лісоводський професійний аграрний ліцей», с. Лісоводи, 32046, вул. Сугерова, 4, тел.: (098) 407-73-65, e-mail: gytnatali1 @ gmail.com

\title{
ФОРМУВАННЯ КОМУНІКАТИВНОЇ КОМПЕТЕНТНОСТІ У ВИКЛАДАЧІВ ПРОФЕСІЙНО-ТЕХНІЧНИХ НАВЧАЛЬНИХ ЗАКЛАДІВ
}

Анотація. Ця стаття націлена на комплексний аналіз комунікативної компетентності викладачів у контексті організації освітнього процесу у професійно-технічних навчальних закладів. У роботі, що пропонується до уваги, проаналізовано різні підходи до тлумачення поняття компетентності, визначено місце комунікативної компетентності в системі ключових особистісних компетенцій викладача. У світі все більшу роль відіграє вміння людей взаємодіяти один з одним - від цього залежить ефективність роботи, рівень взаємовідносин. 31990 року у документах ЮНЕСКО окреслюється коло компетенцій (до його складу входить комунікативна компетенція), які мають розглядатися як бажаний результат освіти. Комунікативна компетентність набула особливого статусу в процесі реформування системи освіти в Україні. У роботі окреслено становлення нових перспективних та інноваційних підходів до навчання саме в галузі професійно-технічної освіти (засвоєння наукових знань і набуття практичного досвіду відбувається під знаком професійної спрямованості, тобто у плані підготовки до діяльності в галузі обраної професії; вивчення навчальних дисциплін у розвитку - здобувачі освіти опановують наукові знання та методи їх інтерпретації, знайомляться із проблемами, завданнями та способами їх вирішення; поєднання наукового й навчального процесів - самостійна навчально-пізнавальна діяльність студентів протікає разом 3 дослідницькою роботою). Поняття комунікативної та 
комунікаційної компетенції не є тотожними за значенням, проте нормою спілкування у сучасному світі стало використання сучасних новітніх комунікаційних засобів, зокрема, інформаційних технологій. Тому звичайна мовна комунікація нині широко використовується у площині комп'ютерних інтернет-технологій. Значна увага у роботі привернута до ролі інформаційнокомунікаційної компетентності викладача сучасного закладу професійнотехнічної освіти, як складової його комунікативної компетентності. Важливою умовою виконання професійних функцій педагогів, вирішення основних дидактичних та навчально-виховних завдань стає комунікативна компетентність, яка $\epsilon$ відображенням професійної компетентності викладача в цілому. Виокремлено основні проблеми формування комунікативної компетентності у викладачів професійно-технічних закладів освіти.

Ключові слова: комунікативна компетентність, комунікативні технології, професійно-технічна освіта, освітній процес.

Dzera Natalia Anatoliivna Teacher of the highest category, senior teacher, teacher of chemistry and biology, State Educational Institution "Professional agricultural lyceum of Lisowody", Sugerova St., 4, Lisowody, 32046, tel.: (097) 897-71-01, e-mail: nataliadzera73@gmail.com

Chubinska Nataliia Bogdanivna Associate Professor, Department of Pedagogy and Innovative Education, Institute of Law, Psychology and Innovative Education, Lviv Polytechnic National University, Bandery St., 14, Lviv, 79000, tel.: (067) 813-01-58, e-mail: nataliialviv2015@gmail.com, https://orcid.org/0000-0002-4803-2453

Zemlyak Natalia Ivanivna Teacher of the highest category, teachermethodologist, teacher of Ukrainian language and literature, State Educational Institution "Professional agricultural lyceum of Lisowody", Sugerova St., 4, Lisowody, 32046, tel.: (098) 407-73-65, e-mail: gytnatali1 @ gmail.com

\section{FORMATION OF COMMUNICATIVE COMPETENCE IN TEACHERS OF VOCATIONAL AND TECHNICAL EDUCATIONAL INSTITUTIONS}

Abstract. This article is aimed at a comprehensive analysis of the communicative competence of teachers in the context of the organization of the educational process in vocational education institutions. In the proposed work, different approaches to the definition of competence are analyzed, the place of communicative competence in the system of key personal competencies of the teacher is determined. In the world, the ability of people to interact with each other plays an increasing role - it depends on the efficiency of work, the level of relationships. Since 1990, UNESCO documents have outlined the range of competencies (which include communicative competence) that should be considered as a desirable educational outcome. Communicative competence has acquired a 
special status in the process of reforming the education system in Ukraine. The paper outlines the formation of new promising and innovative approaches to learning in the field of vocational education (acquisition of scientific knowledge and gaining practical experience is under the sign of professional orientation, ie in terms of preparation for activities in the chosen profession; study of disciplines in development - students master scientific knowledge and methods of their interpretation, get acquainted with problems, tasks and solutions ; combination of scientific and educational processes - independent educational and cognitive activity of students proceeds together with research work). The concepts of communicative and communicative competence are not identical in meaning, but the norm of communication in the modern world has become the use of modern latest communication tools, in particular, information technology. Therefore, conventional language communication is now widely used in the field of computer Internet technology. Considerable attention in the work is drawn to the role of information and communication competence of the teacher of a modern institution of vocational education, as a component of its communicative competence.An important condition for the performance of professional functions of teachers, the solution of basic didactic and educational tasks is communicative competence, which is a reflection of the professional competence of the teacher as a whole. During the processing of the material the following methods were used: analysis of online publications, psychological and pedagogical works, scientific and methodological literature on the subject. The main problems of formation of communicative competence in teachers of vocational education institutions are highlighted.

Keywords: communicative competence, communicative technologies, vocational education, educational process.

Постановка проблеми. Для здобувачів професійно-технічної освіти на сучасному етапі значно зростає та змінюється роль викладача, який стає, насамперед, керівником самостійної роботи студентів, зачинателем їх творчої активності, прагнення до професійного та особистісного вдосконалення. -

Актуальний стан проблеми окреслюється сучасними вимогами до особистості викладача, його компетентностей. Потребує дослідження питання особливостей формування педагогічної компетентності викладача сучасного закладу професійно-технічної освіти, яка гіпотетично складаються не лише із високого рівня знання свого предмета та вміння його викладати в аудиторії, а й, значною мірою, із системи особистісних якостей педагога, які гармонійно реалізуються у професійній діяльності.

Аналіз останніх досліджень і публікацій. Важливі аспекти формування комунікативної компетентності особистості висвітлюються такими українськими вченими як О. Волченко, Т. Дячкова, Т. Колодько, В. Лозова, В. Нетреба, С. Ніколаєва, Т. Симоненко, Г. Хорошавіна та ін. Структуру комунікативної компетентності обгрунтували Н. Бібік, H. Волкова, Ю. Вторнікова, С. Петрушин, О. Савченко, О. Тищенко. Беручи до уваги 
існуючі напрацювання зазначених вище дослідників за даною темою, однак, слід акцентувати увагу на питаннях, які залишаються недостатньо розробленими i невирішеними як у теоретичному, так i в практичному аспектах. До таких слід віднести саме формування комунікативної компетентності у педагогів професійно-технічних навчальних закладів.

Метою статті $\epsilon$ комплексний аналіз комунікативної компетентності викладачів у контексті організації освітнього процесу у професійно-технічних навчальних закладів.

Виклад основного матеріалу. На сучасному етапі розвитку українського суспільства відбувається реформування освіти, робиться спроба реорганізації освітніх моделей. Науковці, педагоги, методисти прагнуть оновлення освіти, наполягаючи на відмові від репродукції знань, оскільки сама по собі інформація втрачає вагу, якщо немає прикладного характеру, тоді як добування інформації стало пріоритетним у діяльності людини. Відпадає необхідність перевантажувати пам'ять певними знаннями, зростає потреба вміти користуватися ними. Однією 3 причин відставання освіти від запитів сьогодення $\epsilon$ недостатньо обгрунтований підхід до того, якою має бути компетентна особистість викладача, якими якостями повинен він володіти для того, щоб успішно виконувати завдання, які висуває перед здобувачами освіти сучасне інформаційне суспільство. В умовах постіндустріального суспільства особливо важливими стають не стільки конкретні професійні вміння та навички, a i загальні здібності набувати знань, використовувати їх для вирішення великої кількості складних задач, аналізувати інформацію, виділяти суттєве, мислити критично.

У межах даної аналітичної розвідки нас цікавить процес формування комунікативної компетентності викладача сучасного закладу професійнотехнічної освіти. Тому, насамперед, розглянемо, як визначається освітній процес в цілому та конкретно у професійно-технічних закладах - його компоненти та особливості.

У сучасній довідковій літературі поняття «освітній процес» визначене, як цілеспрямований педагогічний процес організації й стимулювання активної навчально-пізнавальної діяльності студентів з оволодіння науковими знаннями, уміннями й навичками, розвитку творчих здібностей, світогляду, моральноетичних поглядів і переконань [15]. Як бачимо, це, по суті, не визначення, а перелік завдань (оволодіння науковими знаннями, уміннями й навичками, розвиток творчих здібностей, світогляду, морально-етичних поглядів i переконань студентів), а також засобів, за допомогою яких ці завдання вирішуються (організація й стимулювання активної навчально-пізнавальної діяльності студентів). Відтак, у даному підході відображено лише процесуальний характер освітнього процесу, а не розкривається його зміст $\mathrm{i}$ сутність.

Освітній процес у професійно-технічних навчальних закладах - це спеціальна форма передачі й засвоєння суспільно-історичного досвіду, 
придбаного людьми протягом століть і вираженого у вигляді системи наукових знань, суджень, правил тощо. Він містить у собі дві органічно пов'язані діяльності, а саме: викладання - діяльність викладача у процесі навчання, спрямована на організацію навчальної діяльності студентів, планомірну, систематичну передачу змісту освіти й формування необхідних якостей особистості; учіння - процес діяльності того, хто навчається (як під керівництвом, так і в ході самоосвіти), спрямований на засвоєння змісту освіти й досвіду навчально-пізнавальної діяльності [12, с. 108].

В освітньому процесі досить дискусійним є становище того, хто навчається, оскільки він виступає тут у двох іпостасях - і об'єкта, і суб'єкта. У навчанні два суб'єкти - той, хто навчає, і той, кого навчають. I те, що «той, кого навчають, повинен стати й об'єктом, і суб'єктом навчання», є одним із вирішальних методологічних принципів педагогіки, який на сьогодні визначений у якості спрямовуючого вектору розвитку педагогічної науки [6, с. 52].

Отже, під поняттям «освітній процес» можна розуміти специфічний процес навчання у професійно-технічному навчальному закладі, який охоплює усі складові: діяльність викладача, діяльність тих, хто навчається, засобів, за допомогою яких здійснюється цей процес, форми, у яких він реалізується.

Основними функціями освітнього процесу є навчальна, розвивальна та виховна. Поряд з ними також виконується комунікативна функція. Провідні функції освіти доповнюються професійною функцією. Їі значення виявляється в тому, що освітній процес набуває професійної спрямованості, що однак не означає його орієнтацію на суто прикладний характер [14, с. 115].

Далі звернемося до аналізу підходів вчених до визначення компетентності та, зокрема, комунікативної компетентності, визначимо іiі місце в системі ключових компетентностей особистості.

У сучасній педагогічній літературі вживання цих понять пов’язане найчастіше 3 розглядом проблеми невідповідності вимог до компетентного спеціаліста (викладача) та існуючої моделі освіти, тобто в рамках так званого компетентнісного підходу, що висуває на перше місце не поінформованість учня, не «багаж знань», накопичених у процесі фахової підготовки у навчальному закладі, а вміння розв'язувати проблеми, що виникають у різних видах діяльності, у сферах етичних, соціальних, правових, професійних, особистих взаємовідносин. 3 огляду на дуже швидке застарівання інформації у сучасному суспільстві, запропонований підхід передбачає такий вид змісту освіти, який не зводиться до знаннєво орієнтованого компонента, а передбачає цілісний досвід вирішення життєвих проблем, виконання ключових (тобто тих, що належать до багатьох соціальних сфер) функцій, соціальних ролей, компетенцій $[1 ; 4 ; 10]$.

Термін «компетентність» 3’явився у вітчизняній педагогіці внаслідок аналізу основних тенденцій розвитку зарубіжної педагогіки та є перекладом англійського слова «соmpetence» тлумачить «соmpetence» як «the ability to do 
something well; a skill that you need in a particular job or for a particular task» [16]. Тобто, за цим визначенням, компетентність - це здатність робити щось добре; уміння, необхідні для виконання певної роботи чи завдання.

Останнім часом у педагогіці можна простежити тенденцію до виокремлення важливості практичного досвіду у процесі передачі та отримання знань. У таких дослідженнях компетентність розглядається не стільки як знання, уміння, навички, скільки як досвід людини, як складний синтез когнітивного, предметно-практичного та особистісного способу самореалізації або форми прояву здібності. На думку українського науковця В. Нетреби, компетентність - це загальна здатність, що базується на знаннях, досвіді, цінностях, здібностях, набутих завдяки навчанню [9].

Згідно досліджень О. Тищенка, компетентність можна розглядати під чотирма кутами зору [13]:

1) поєднання вмінь, навичок поведінки та дій у межах певної діяльності;

2) поєднання знань, умінь, навичок у професійній діяльності без критеріїв оцінювання;

3) поєднання тих самих елементів, але із застосуванням стандартів;

4) поєднання здібностей та особистих якостей людини.

Таким чином, можемо зробити висновок, що компетентність - це особистісна характеристика, яка означає здатність самостійно вирішувати життєві проблеми і завдання в конкретних життєвих ситуаціях, уміти мобілізуватися, застосовувати знання, вміння, досвід та творчий потенціал відповідно до ситуації, адекватної суспільним, культурним та економічним умовам суспільства.

На думку А. І. Петренка, комунікативна компетентність - це вміння будувати ефективну мовну діяльність та ефективну мовленнєву поведінку, що відповідають нормам соціальної взаємодії [11]. 3 точки зору Н. Сиско, комунікативна компетентність - це здатність людини до спілкування в одному або всіх видах мовної діяльності, яка $\epsilon$ придбаною в процесі природної комунікації або спеціально організованого навчання [12].

Серед цих характеристик комунікативної компетентності можна виділити три основних компоненти: а) лінгвістична компетентність передбачає оволодіння певними знаннями та навичками у різних аспектах мови: лексиці, фонетиці, граматиці, а також їх когнітивну організацію; б) соціолінгвістична компетентність є здатністю здійснювати вибір мовних форм, використовувати їx i перетворити відповідно до контексту; в) прагматична компетентність включає знання, вміння, навички, що дозволяють розуміти і породжувати висловлювання відповідно до конкретної ситуації спілкування.

Наявність у людини комунікативної компетентності дозволяє ій взаємодіяти з іншими людьми в побутовій, навчальній, виробничій, культурній та інших сферах життєдіяльності, використовуючи різні знакові системи (серед яких мова $є$ домінуючою).

Під комунікативною компетентністю викладача прийнято розуміти рівень 
Журнал«Герспективитаінновації наукиљ

(Серія«Гедагогіка», Серія«ГЕихологія», Серія «Медицин»

№5(5) 2021

володіння викладачем знаннями та вміннями організації ефективної взаємодії iз учнями, що спирається на потреби та цінності освітнього процесу та забезпечує його якість [9].

Тобто комунікативна компетентність передбачає, поряд із високим рівнем культури мови та здатністю викладати свої думки, вміння встановити психологічний контакт 3 аудиторією, вибір методів взаємодії та засобів переконання, а також усвідомлення своєї ролі у комунікативному процесі.

Також, ïi складовими $є$ такі якості, як доброзичливість, ввічливість, тактовність; вміння вислухати та прагнення зрозуміти співрозмовника; толерантність; витримка та вміння спокійно реагувати на будь-які реакції 3 боку студентів.

У психолого-педагогічній літературі компетентність викладача, зокрема i комунікативна, сприймається як складне утворення, що включає у себе ряд показників (компонентів) [2; 7].

Проаналізувавши представлені підходи до комунікативної компетентності, можна виділити іiі наступні ключові компоненти: 1) ціннісно-мотиваційний сукупність мотивів та цінностей, що спрямовують професійне спілкування викладача та визначають його готовність до розвитку комунікативної компетентності; 2) когнітивний - сукупність професійно-педагогічних та психологічних знань у цій галузі; 3) операційний - володіння методами, прийомами та формами організації взаємодії з суб’єктами освітнього процесу, здатність та готовність до його реалізації у різноманітних стандартних та нестандартних ситуаціях; 4) регулятивний - здатність контролювати та коригувати взаємодію з учнями та колегами; 5) рефлексивний - вміння адекватно оцінювати власні вчинки та поведінку у ситуаціях професійного спілкування.

Слід зазначити, що комунікативна компетентність викладачів формується за умови професійного спілкування зі студентами, безпосередньої участі в освітньому процесі певної категорії навчальних закладів [8].

Отже, звернемося до аналізу специфіки організації освітнього процесу в середніх професійно-технічних училищах, яка полягає у наступному:

- $\quad$ процес навчання відбувається за умов зорієнтованості студентів на отримання конкретної професії. Це впливає на мотиви вчення, визначає, як правило, підвищений інтерес студентів до спеціальних предметів та виробничого навчання;

- $\quad$ існує тісний зв'язок навчання 3 продуктивною працею студентів. Це визначає загальну прикладну професійну спрямованість навчального процесу, орієнтацію на оволодіння студентами вміннями застосовувати знання для вирішення практичних завдань;

- взаємозв'язок загальних цілей розумового розвитку студентів та цілей формування їх технічного мислення;

- особливу роль в училищах відіграють майстри виробничого навчання, які є вчителями професії, вихователями та наставниками студентів; 
це значною мірою впливає на організацію освітнього процесу в училищах та багато в чому визначає специфіку діяльності викладачів щодо навчання та виховання студентів;

- здобувачі у середніх профтехучилищах одночасно отримують загальноосвітню та професійно-технічну підготовку, що обумовлює необхідність здійснювати освітній процес на основі їхнього тісного взаємозв’ язку та взаємозалежності;

- режим освітнього процесу такий, що теоретичне навчання чергується з виробничим.

Таким чином, основними особливостями навчання у закладах професійнотехнічної освіти є наступні:

засвоєння наукових знань i набуття практичного досвіду відбувається під знаком професійної спрямованості, тобто у плані підготовки до діяльності в галузі обраної професії;

- вивчення навчальних дисциплін у розвитку. Здобувачі освіти опановують наукові знання та методи їх інтерпретації, знайомляться із проблемами, завданнями та способами їх вирішення;

- поєднання наукового й навчального процесів. Самостійна навчально-пізнавальна діяльність студентів протікає разом 3 дослідницькою роботою.

Освітній процес може бути представлений у вигляді комплексу співвіднесених і взаємообумовлених компонентів певної системи. Така система носить характер складної адаптованої поведінки сторін - того, хто навчається, i того, хто навчає, на основі руху й аналізу навчальної інформації.

Виходячи 3 цього, основними структурними елементами освітнього процесу виступають: цілі навчання, які $\epsilon$ ідеальною моделлю бажаного результату засвоєння змісту освіти; зміст освіти, під яким розуміється педагогічно адаптований соціальний досвід; методи навчання й учіння; організаційні форми навчання; реальний результат.

Побудова системи освітнього процесу, перш за все, виходить із загальних завдань професійно-технічної освіти щодо якісної професійної підготовки фахівця.

Розглядаючи систему засобів освіти в професійно-технічних навчальних закладах, доречно зупинитися на їі складових частинах.

Перерахуємо характерні риси освітнього процесу у закладах професійнотехнічної освіти, що забезпечується викладачами загальноосвітніх та спеціальних предметів, майстрами виробничої практики із застосуванням системи засобів навчання, до складу якої входять засоби навчання, що функціонують на базі нових комунікативних та інформаційних технологій. До них відносяться: автоматизація процесів обробки, передачі інформації про об'єкти вивчення та управління навчанням; організація інформаційнонавчальної та експериментально-дослідницької діяльності; організація самостійної навчальної діяльності за поданням і вилучення знань, забезпечення 
предметності діяльності із засобами нових комунікаційних та інформаційних технологій, ïі практична спрямованість.

Застосування засобів сучасних інформаційно-комунікаційних технологій в освітньому процесі закладів професійно-технічної освіти, на наш погляд, забезпечується наявністю програмно-методичного забезпечення, орієнтованого на підтримку процесу викладання певного навчального предмета (предметів) або курсу (курсів), які мають складатися з:

- програмних засобів підтримки процесу викладання;

- інструментальних програмних засобів, що забезпечують можливість автоматизації процесу контролю результатів навчальної діяльності, а також управління навчанням;

- об'єктно-орієнтованих програмних систем (наприклад, система підготовки текстів, база даних, електронні таблиці, різні графічні та музичні редактори);

- засобів навчання, що функціонують на базі нових інформаційних технологій, застосування яких забезпечує предметність діяльності (iі наочність), iii практичну спрямованість (наприклад, навчальні роботи 3 використанням електронних конструкторів, пристроїв, інтернет-засобів);

- предметно-орієнтованого середовища навчального і розвиваючого призначення.

У сучасній педагогічній практиці вітчизняної освіти їх створення здійснюється в основному на базі програмної реалізації, зокрема мультимедійної технології.

Можна говорити про те, що одною 3 основних цілей закладів освіти, зокрема професійно-технічної, є підготовка спеціалістів, які здатні вести конкурентоспроможну діяльність у сучасному суспільстві, яке дуже швидко трансформується.

Засоби навчання, у тому числі i ті, що функціонують на базі нових інформаційних технологій, в сукупності з навчально-методичними матеріалами (підручники, навчальні посібники для учнів, методичні посібники, рекомендації для викладача) утворюють певну цілісність, представлену певним складом i структурою - навчально-методичним комплексом дисципліни, викладання якої забезпечується комунікативно компетентними викладачами.

Виходячи 3 вищезазначеного, наявна можливість окреслити основні проблеми формування комунікативної компетентності у викладачів професійно-технічних закладів освіти.

Багато викладачів неодноразово стикалися у своїй професійній практиці 3 тим, що, чудово знаючи свій предмет, не могли залучити своїх студентів до освітнього процесу. Можливо, проблема полягає у відсутності особистісноорієнтованої комунікації з ними.

На наш погляд, маркером сформованості комунікативної компетентності у викладачів, а також майстрів виробничого навчання професійно-технічних навчальних закладів $\epsilon$, передусім, успішне мовне спілкування зі студентами на 
особистісному рівні. Пропонуємо розглянути взаємодію іï складових (рис.1).

\section{КОМУНІКАТИВНА КОМПЕТЕНТНІСТЬ}

об’єктивне сприйняття партнерів по взаємодії, знаходження адекватного стилю й тону спілкування, урахування індивідуальних особливостей, вміння активно слухати, вільно володіти вербальними, невербальними, комп'ютерними засобами комунікації

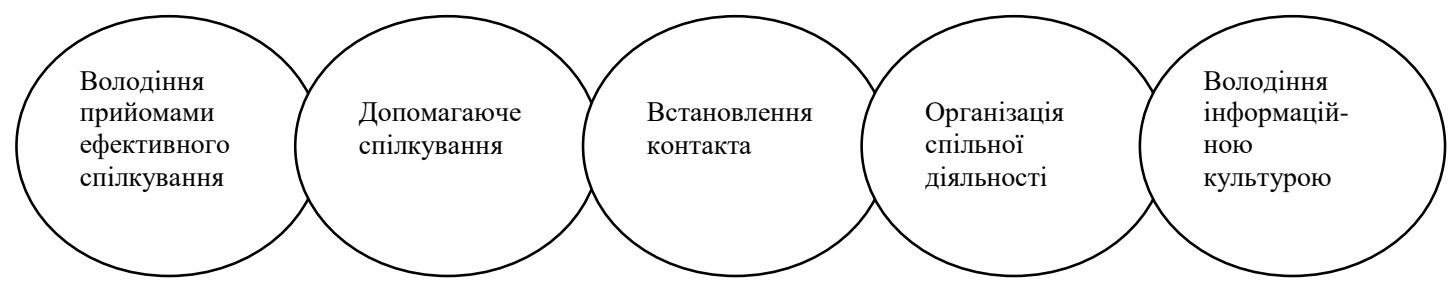

Pис.1. Складові комунікативної компетентності на особистісному рівні Джерело: авторська розробка

Кожен викладач повинен суворо контролювати свою мовну поведінку i постійно вдосконалювати свої мовні навички та вміння. Педагог, який не володіє достатнім рівнем комунікативної компетентності, не здатний реалізувати особистісно-орієнтовані освітні технології, не готовий гнучко керувати процесом під час навчання та виховання, сприяти взаєморозумінню, застосовувати комунікативні технології.

Особливістю формування комунікативної компетентності викладачів у сучасних умовах розвитку інноваційних технологій є здатність до взаємодії 3 новітніми комунікативними засобами, зокрема володіння інструментами для проведення відеоконференцій з використанням Zoom, Skype, Microsoft Teams.

Висновки. Таким чином, основою педагогічної майстерності $є$ знання свого предмета, що реалізується через комунікативні якості. Крім того, комунікативна компетентність викладача означає підвищення уваги до особистості студента. Вміння викладача бачити його індивідуальнопсихологічні особливості, враховувати їх при виборі форм педагогічної взаємодії може відігравати значну роль у формуванні мотивації до набуття професійних та загальнокультурних знань, умінь, навичок, ціннісних орієнтирів. 3 цього випливає, що викладач, поряд 3 професійними, повинен мати знання в галузі психології та педагогіки: знати характерні психологопедагогічні особливості підліткового та юнацького віку, індивідуальнотипологічні характеристики особистості, особливості перебігу пізнавальних психічних процесів, форми мотивованої поведінки та закономірності розвитку мотиваційної сфери особистості, основні види та способи педагогічної взаємодії. 
Прагнення викладача опанувати ефективні способи вирішення комунікативних завдань, технології педагогічного спілкування, безумовно, $\epsilon$ одним 3 найважливіших показників ефективності його професійної діяльності.

\section{Лimepamypa:}

1. Баловсяк Н. В.Концепція визначення структури інформаційної компетентності фахівця. Мелітополь: МДПУ, 2006. 30 с.

2. Бібік Н. М. Компетенції. Енциклопедія освіти. Київ : Юрінком Інтер, 2008. С. 409 -410.

3. Биков В. Ю. Методологічні та методичні основи створення і використовування електронних засобів навчального призначення. 2012. №2. С. 3-6.

4. Дячкова Т. В. Педагогіка професійно-технічної освіти: навч. посіб. Херсон: Айлант, 2003. 476 с.

5. Жалдак М. I. Система підготовки вчителя до використання інформаційнокомунікаційних технологій в навчальному процесі. Науковий часопис НПУ імені М. П. Драгоманова. 2011. С. 76-82.

6. Жук Ю. О., Соколюк О. М., Дементієвська Н. П., Пінчук О. П. Організація навчальної діяльності у комп'ютерно-орієнтованому навчальному середовищі. Київ: Педагогічна думка, 2012. 128 с.

7. Лозова В. І. Формування педагогічної компетентності викладачів вищих навчальних закладів освіти. Педагогічна підготовка вищих навчальних закладів: матеріли міжвузівської науково-практичної конферениії. Х.: «ОВС», 2002. 164 с.

8. Малихін О. В., Павленко І. Г., Лаврентьєва О. О., Матукова Г. І. Методика викладання у вищій школі: навч. посіб. Сімферополь: «Дайфі», 2011. 270 с.

9. Нетреба В. Компетентності шлях до оновлення освіти. Київ: Плеяди, 2005. 105 с.

10. Педагогічна книга майстра виробничого навчання: навч.-метод. посібник / ра ред. Н. Г. Ничкало. Київ: Вища школа, 1994. 208 с.

11. Петренко А. І. Європейський досвід дослідження та розроблення новітніх навчальних технологій для інформаційного суспільства. Київ: Університет «Україна», 2004. С. 371-379.

12. Сиско Н.М. Системний підхід до професійного розвитку викладачів закладів професійної (професійно-технічної) освіти. Науковий вісник Мукачівського державного. 2019. С. 107-110.

13. Тищенко O. I. Загальнонаукові засади дослідження поняття професійної компетентності. Освіта запорізького краю. URL : http://virtkafedra.ucoz.ua/el_gurnal/pages/ vyp10/tishenko.pdf (дата звернення: 27.11.2021).

14. Фіцула М. М. Педагогіка: навч. посіб. для студентів вищих педагогічних закладів освіти. Київ, 2002.528 с.

15. Харламов I. Ф. Педагогіка. Краткий курс. URL: https://ukrdoc.com.ua/text/40591/ index-1.html (дата обращения: 27.11.2021).

16. Oxford Advanced Lerner's Dictionary of Current English. 6th edition. Oxford University Press, 2000, 1568 c.

\section{References:}

1. Balovsiak, N. V. (2006) Kontseptsiia vyznachennia struktury informatsiinoi kompetentnosti fakhivtsia [The concept of determining the structure of information competence of the specialist]. Melitopol: MDPU [in Ukrainian].

2. Bibik, N. M. (2008) Kompetentsii. Entsyklopediia osvity [Encyclopedia of Education] K.: Yurinkom Inter, 409-410 [in Ukrainian].

3. Bykov, V. Yu. (2012) Metodolohichni ta metodychni osnovy stvorennia i vykorystovuvannia elektronnykh zasobiv navchalnoho pryznachennia [Methodological and methodical bases of creation and use of electronic means of educational purpose], 2, 3-6 [in Ukrainian]. 
4. Diachkova, T. V. (2003) Pedahohika profesiino-tekhnichnoi osvity [Pedagogy of vocational education]. Kherson: Ailant [in Ukrainian].

5. Zhaldak, M. I. (2011) Systema pidhotovky vchytelia do vykorystannia informatsiinokomunikatsiinykh tekhnolohii $\mathrm{v}$ navchalnomu protsesi [The system of teacher training for the use of information and communication technologies in the educational process]. Naukovyi chasopys NPU imeni M. P. Drahomanova, 76-82 [in Ukrainian].

6. Zhuk, Yu. O., Sokoliuk, O. M., Dementiievska, N. P., Pinchuk, O. P. (2012) Orhanizatsiia navchalnoi diialnosti u kompiuterno-oriientovanomu navchalnomu seredovyshchi [Organization of educational activities in a computer-oriented learning environment] K.: Pedahohichna dumka [in Ukrainian].

7. Lozova, V. I. (2002) Formuvannia pedahohichnoi kompetentnosti vykladachiv vyshchykh navchalnykh zakladiv osvity [Formation of pedagogical competence of teachers of higher educational institutions]. Pedahohichna pidhotovka vyshchykh navchalnykh zakladiv: materily mizhvuzivskoi naukovo-praktychnoi konferentsii. X.: «OVS» [in Ukrainian].

8. Malykhin O. V., Pavlenko I. H., Lavrentieva O. O., Matukova H. I. Metodyka vykladannia u vyshchii shkoli: navchalnyi posibnyk [Methods of teaching in high school ]. Simferopol: «Daifi» [in Ukrainian].

9. Netreba, V. (2005) Kompetentnosti shliakh do onovlennia osvity [Competences are a way to renew education ] K.: Pleiady [in Ukrainian].

10. Pedahohichna knyha maistra vyrobnychoho navchannia [Pedagogical book of the master of industrial training] / Za red. N. H. Nychkalo. K.: Vyshcha shkola [in Ukrainian].

11. Petrenko, A. I. (2004) Yevropeiskyi dosvid doslidzhennia ta rozroblennia novitnikh navchalnykh tekhnolohii dlia informatsiinoho suspilstva. [European experience of research and development of the latest educational technologies for the information society] K.: Universytet «Ukraina», 371-379 [in Ukrainian].

12. Sysko, N.M. (2019) Systemnyi pidkhid do profesiinoho rozvytku vykladachiv zakladiv profesiinoi (profesiino-tekhnichnoi) osvity [A systematic approach to the professional development of teachers of vocational (vocational) education]. Naukovyi visnyk Mukachivskoho derzhavnoho, 107-110 [in Ukrainian].

13. Tyshchenko, O. I. Zahalnonaukovi zasady doslidzhennia poniattia profesiinoi kompetentnosti [General scientific principles of research of the concept of professional competence. Osvita zaporizkoho kraiu. Retrieved from: http://virtkafedra.ucoz.ua/el_gurnal/ pages/vyp10/tishenko.pdf [in Ukrainian]

14. Fitsula, M. M. Pedahohika [Pedagogy]. K. [in Ukrainian].

15. Kharlamov, I. F. Pedahohika. Korotkyi kurs [Pedagogy. Short course.] Retrieved from: https://ukrdoc.com.ua/text/40591/index-1.html [in Russian].

16. Oxford Advanced Lerners Dictionary of Current English (2000). 6th edition. Oxford University Press [in English]. 